\begin{tabular}{|c|c|c|c|c|}
\hline \multirow{2}{*}{$\begin{array}{l}\text { ピクラート } \\
\text { 融点 }\left({ }^{\circ} \mathrm{C}\right)\end{array}$} & \multirow{2}{*}{ 再絬晶溶媒 } & \multirow{2}{*}{ 分子式 } & \multicolumn{2}{|c|}{ 窒素分析值 $N(\%)$} \\
\hline & & & 計算値 & 分析值 \\
\hline $134 \sim 135$ & ベンゼン & $\mathrm{C}_{23} \mathrm{H}_{28} \mathrm{~N}_{4} \mathrm{O}_{9}$ & 11.37 & 11.05 \\
\hline $112.5 \sim 113$ & ペソゼソ & $\mathrm{C}_{23} \mathrm{H}_{27} \mathrm{~N}_{5} \mathrm{O}_{11}$ & 12.75 & 12.84 \\
\hline $137 \sim 138$ & ベンゼン & $\mathrm{C}_{23} \mathrm{H}_{27} \mathrm{~N}_{5} \mathrm{O}_{11}$ & 12.75 & 12.84 \\
\hline $120.5 \sim 121$ & ベンゼン & $\mathrm{C}_{23} \mathrm{H}_{27} \mathrm{~N}_{5} \mathrm{O}_{11}$ & 12.75 & 12.61 \\
\hline $138.5 \sim 139$ & ベンゼン & $\mathrm{C}_{24} \mathrm{H}_{30} \mathrm{~N}_{4} \mathrm{O}_{9}$ & 10.80 & 10.87 \\
\hline $117 \sim 118$ & エタノール & $\mathrm{C}_{24} \mathrm{H}_{29} \mathrm{~N}_{5} \mathrm{O}_{11}$ & 12.43 & 12.37 \\
\hline $144 \sim 145$ & エタノール & $\mathrm{C}_{24} \mathrm{H}_{29} \mathrm{~N}_{5} \mathrm{O}_{11}$ & 12.43 & 12.66 \\
\hline $165 \sim 166$ & ベンゼン & $\mathrm{C}_{24} \mathrm{H}_{29} \mathrm{~N}_{5} \mathrm{O}_{11}$ & 12.43 & 12.33 \\
\hline
\end{tabular}

族酸塭化物とを $50^{\circ} \mathrm{C}$ 以下に冷却して，はげしくかきまぜながら 混合与る。 $45^{\circ} \sim 70^{\circ} \mathrm{C}$ で 30〜120 分間加温しながら反応を行なう と, 混會物は粘稠な液状となり，これを室温まで泠却すると次第 に固化する。得られた固体をエタノールに溶解して, 活性炭で処 理したのちエタノールを留去して得られる白色固体を適当な溶媒 から再結晶すると, 白色の $N$-ベンゾィルオキシアルキルコペリ ジン塩酸塩が得られる。得られた生成物をエタノールに溶解し て, ピクリン酸のエタノール溶液を加えると黄色の沈殿が生成す る。この沈殿を口過, 乾燥したのち 適当な溶媒から再結晶する と, $N$-ベンゾイルオキシアルキルコペリジンのピクラートが得ら れる。 $N$-ベンゾイルオキシアルキルコペリジン塩酸塩の種類,
生成条件, 融点, 収率, 分析值ならびにピクラートの融点を表 2 に示した。

\section{$2.5 N$-ニトロベンゾイルオキシアルキルコペリジン㙁酸塩の}

䢱元

ニトロ誘導体( $\mathrm{U} \sim$ 纤 および $\mathrm{X} \sim \mathrm{XI}$ ) $2 \sim 3 \mathrm{~g}$ を $50 \sim 70 \mathrm{ml}$ のエ タノールに溶かして， $0.05 \sim 0.07 \mathrm{~g}$ の Adams の酸化白金を加 えて, Hershberg の電磁カキマゼ式常圧還元装置により, 常圧下 $37^{\circ} \sim 55^{\circ} \mathrm{C}$ で還元を行なうと 50〜240 分後に理論量の水素が吸収 される。反応終了後室温まで冷却して触媒を口別して, 口液から 減圧下でエタノールを留去したのち残留物を適当な溶媒から再結 晶すると，58〜 77\% の収率で $N$-アミノベンゾイルオキシアルキ ルコペリジンのモノ塩酸塩が得られる。得られた生成物をエタノ ールに溶解して, 過剩のピクリン酸のエタノール溶液を加えると 褐色の油状物が生成するが，これを結晶化することはできなかっ

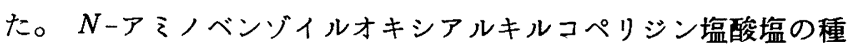
類, 還元条件, 融点, 収率ならびに分析值を表 3 に示した。

本研究の一部は文部省科学研究費によって行なわれた。また試 料の御提供を賜わった三菱化成工業株式会社，ならびに赤外吸収 スペクトルを測定していただいた東北大学理学部化学教室 IRDC の御好意に対して感謝の意を表します。

(1963 年 4 月, 日本化学会第 16 年会講演)

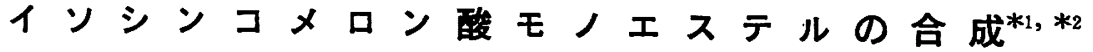

(昭和 41 年 10 月 27 日受理)

\author{
去来川 覚三・故川合 昌路・伏崎 弥三郎*3
}

\begin{abstract}
イソジソコメロソ酸モノェステルおよびそれらの誘導体を合成した。少量の硫酸の存在下でメタノール溶夜中でインシンコメロ ン酸(I)の部分エステル化を行なうと，I の 2-モノメチルエステル(IIa)が得られた。イソシンコメロン酸ジメチルエステル(Ia) を計算量の水酸化カリウムによりメタノール溶液中で部分加水分解すると，Iの5-モノメチルェステル(IVa)が得られた。エタノ 一ル溶媒中で同様に反応を行なうとIの2-モノェチルェステル(IIb)および 5-モノェチルェステル(IVb)が得られた。Ia，Ib，Ia

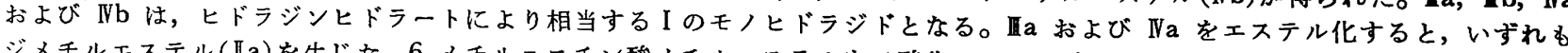
ジメチルエステル(IIa)を生じた。6-メチルニコチン酸メチルェステルを二酸化セレンで酸化すると6-ホルミルニコチン酸メチル エステル $(X)$ となった。Xを過酸化水素で酸化した生成物は，モノメチルェステル(Na)と同一物となった。Xと 2,4-ジニトロフ ェニルヒドラジンとの反応によってXの 2,4-ジニトロフェニルヒドラゾンが得られた。ェターノル溶媒中で $10 \%$ シフン化カリ ウムを用いてX維合すると，5,5'ージメトキシカルボニルー $\alpha$-ビリドインが得られた。
\end{abstract}

\section{1 緒言}

ピリジンジカルボン酸モノエステル類りについては, Kirpal が 合成したキノリン酸モノエステル2)，シンコメロン酸モノエステ *1 この報交を“アルデヒドコリジン誘導体(第 11 報)”
する.

*2 前報(第 10 報), 去来川覚三, 川合昌路, 吉田淑則, 伏 崎弥三郎, 日化，88，550(1967).

*3 Kakuzo Isagawa, Masamichi KawaI, Yasaburo FushiZAKI 大阪府立大学工学部応用化学教室, 堺市百舌鳥梅 町

1) E. Klingsberg, "The Chemistry of Heterocyclic Compounds, Pyridine and Its Derivatives Part 3", John Wiley and Sons, New York-London(1962) p. 238.

2) A. Kirpal, Monatsh., 20, 766(1899).
ル3)，および Mathes らが合成したジピコリン酸モノエステル4 などが報告されているが，イソシンコメロン酸モノエステルにつ いてはまだ報告が見あたらない。本報においては，アルデヒドコ リジンを酸化して得られるイソシンコメロン酸から数種のモノェ ステルを生成することができたので報告する。イソシンコメロン 酸（I ）を少量の硫酸の存在下でメタノールとともに加熱遠流し て部分エステル化するとイソシンコメロン酸-2-メチルエステル (IIa)が得られ，而a をさらにエステル化するとイソシンコメロン 酸ジメルエステル(IIa)が得られた。つぎにジメチルエステル (IIa)をメタノール溶媒中当モルの水酸化カリウムで部分加水分

3) A. Kirpal, Monatsh., 28, 439(1907).

4) W. Mathes, W. Sauermilch, T. Klein, Ber., 86, 584 (1953) 


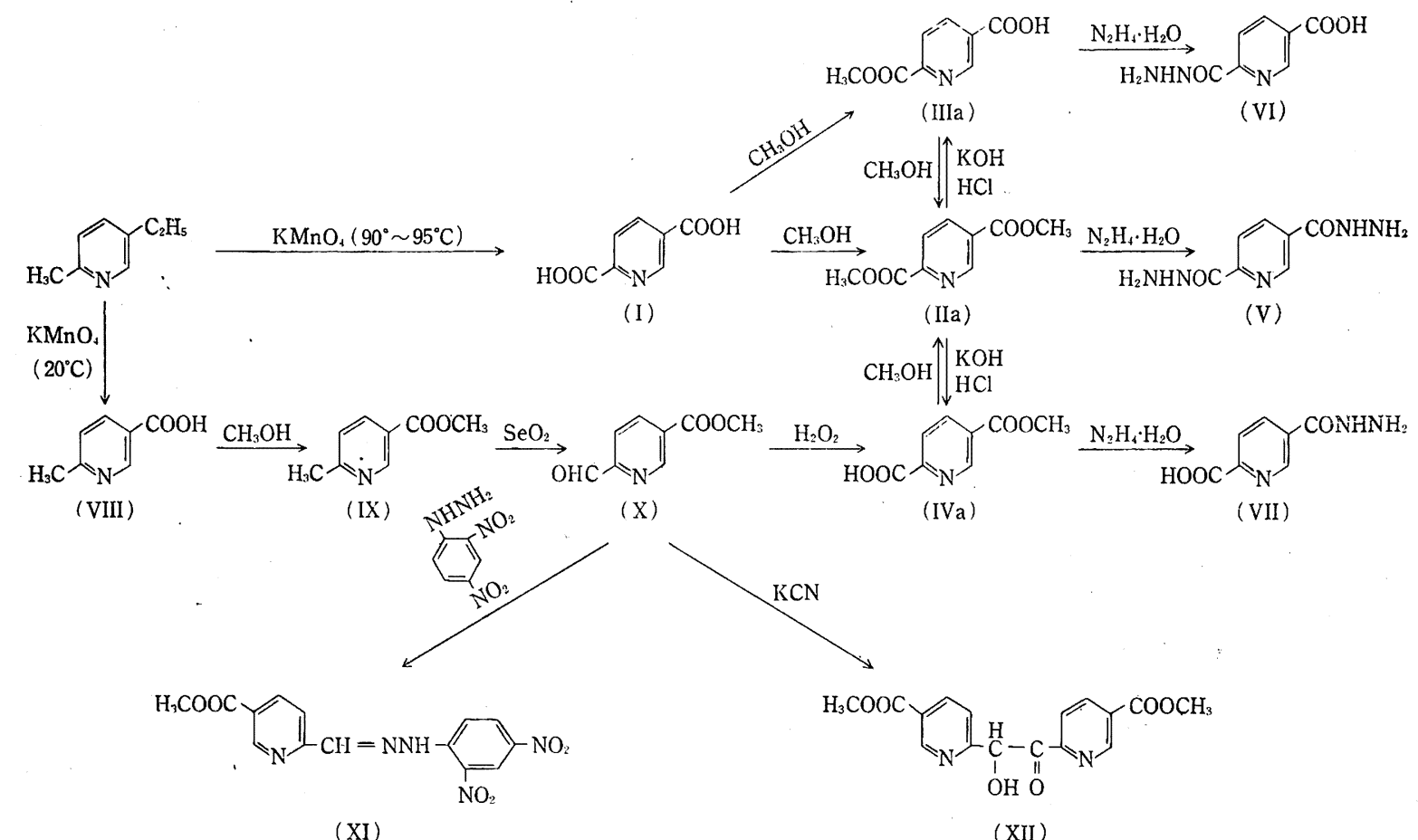

解すると，イソシンコメロン酸-5-メチルエステル(INa)が 得られ た。Iaおよび四a はヒドラシンヒドラートとの反応によって相当 するイソシンコメロン酸ジヒドラジド5)(V)およびイソシンコメ ロン酸-2-ヒドラジドあ( (U)を生成した。 $\mathrm{Na}$ とヒドラジンヒドラ 一トとの反応によって得られるイソシンコメロン酸-5-ヒドラジ ド (II) は文献未載の化合物であるので， IVa の確認を行なうにあ たり，つぎに述べる方法を用いた。アルデヒドコリジンを過マン ガン酸カリウムで $0^{\circ} \sim 20^{\circ} \mathrm{C}$ で酸化7すると，6-メチルニコチン. 酸 (田)が得られるので，䜣 をエステル化して 6-メチルニコチン 酸メチルエステル $(\mathbb{X})$ としたのち， Mathes ら4の方法にしたが

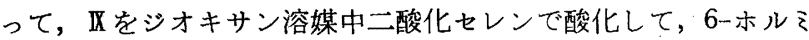
ルニコチン酸メチルエステル(X)を合成した。ピリジンアルデヒ ド $(X)$ は文献末載の化合物であり，Xを過酸化水素で酸化すると アルデヒド基が容易にカルボキシル基に酸化されて，イソシンコ メロン酸モノメチルエステルが得られた。ここに得られたイソシ ンコメロン酸モノメチルエステルは, 前述のモノエステル(Na) と 同じ融点を示し，混融試験の結果融点降下を示さず，赤外吸収ス ペクトル，紫外吸収スペクトルならび元素分析の結果から $\mathbb{N a}$ と 同一物であることが確認された。

イソシンコメロン酸モノメチルエステルの生成法に準じてIを エタノールにより部分エステル化すると，イソシンコメロン酸一 2-エチルエステル(IIb)が得られ，イソシンコメロン酸ジエチル エステル(IIb)を部分加水分解するとイソシンコメロン酸-5-エチ

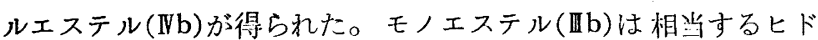
ラジドを生成し，それは III から得られたヒドラジド( U)と同 一物であり， IVb のヒドラジドは VII と同一物であることを確か めた。

5) H. Meyer, F. Staffen, Monatsh., 34, 517(1912).

6) 篠原弘之, 一宮康祐, 吉村達四郎, 大河原信, 高分子 化学, 15, 839(1958).

7）村橋倰介，阪大産研報文，7，127(1950).<smiles>[R]OC(=O)c1ccc(C(=O)O[R20])nc1</smiles>

( II )

( III)<smiles>[R]OC(=O)c1ccc(C(=O)O)nn1</smiles>

(IV)

II a, II a, IVa; $\mathrm{R}=\mathrm{CH}_{3}$

$\mathbb{I} \mathrm{b}$, II b, $\mathbb{V b} ; \mathrm{R}=\mathrm{C}_{2} \mathrm{H}_{5}$

ここに得られたイソシンコメロン酸モノエステル類は，アルデヒ ドコリシンから比較的高収率で得られ，かつ 6-置換ニコチン酸 誘導体あるいは 5-置換ピコリン酸誘導体合成の中間体として用 いることができるので興味あるものと考えられる。ピリジンアル

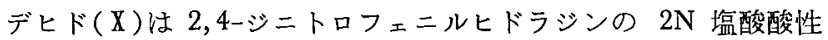
水溶液から相当するヒドラゾン(XI)を生成し，Xのエタノール溶 液にシアン化カリウム水溶液を加えると $5,5^{\prime}$-ジメトキシカルボ ニルー $\boldsymbol{\alpha}$-ピリドイン(XII)を生成した。

\section{2 実験}

\section{1 イソシンコメロン酸 $(\mathbf{I})$}

Carbide and Carbon Chemical 社製品の bp $173^{\circ} \sim 174^{\circ} \mathrm{C}$ の アルデヒドコリジン $50 \mathrm{~g}$ を水に照濁して，反応温度を $90^{\circ}$ ～ $95^{\circ} \mathrm{C}$ にたもちながら過マンガン酸カリウム $500 \mathrm{~g}$ を徐々に加え る。かきまぜながら 1 時間加熱反応したのち, 生成した二酸化マ ンガンをロ別して， 口液を濃塩酸で $p H 1.8$ にすると白色沈殿 が得られる。水から再結晶すると $\mathrm{mp} 251^{\circ} \mathrm{C}$ (分解)のイソシン コメロン酸 $52 \mathrm{~g}$ が得られる。収率 $75.3 \%$

\section{2 イソシンコメロン酸ジメチルエステル $(\mathbf{I I a})$}

I $30 \mathrm{~g}$ に無水メタノール $300 \mathrm{ml}$ と濃硫酸 $30 \mathrm{~g}$ を加えて 8 時間加熱還流する。反応終了後炭酸ナトリウムで中和すると白色 の沈殿が生成する。沈殿を口過乾燥後メタノールから再結晶する と $\mathrm{mp} 164^{\circ} \mathrm{C}$ のイソシンコメロン酸ジメチルエステル $22 \mathrm{~g} を$ 
得る。収率 $62.8 \%$ 。 II り $\mathrm{mp} 267^{\circ} \sim 268^{\circ} \mathrm{C}$ のイソシンコメロン酸ジヒドラジド(V)が 得られる。

\section{3 イソシンコメロン酸ジエチルエステル $(\mathbf{I I b})$}

I $30 \mathrm{~g}$ に無水エタノール $80 \mathrm{ml}$ と濃硫酸 $30 \mathrm{~g}$ を加光て 8 時 間加熱還流する。反応終了後炭酸ナトリウムの飽和溶液を加えて 中和したのちエーテルで抽出する。抽出液を無水硫酸ナトリウム で乾燥したのちエーテルを留去すると白色固体が残留する。エタ ノールから再結晶すると $\mathrm{mp} 46.5^{\circ} \sim 48^{\circ} \mathrm{C}$ のイソシンコメロン 酸ジチルエステル $29 \mathrm{~g}$ を得る。収率 $72.5 \%$ 。

\section{4 インシンコメロン酸の部分エステル化}

2.4 .1 インシンコメロン酸-2-メチルエステル(IIIa): $18.4 \mathrm{~g}$ $(0.05 \mathrm{~mol})$ K $100 \mathrm{ml}$ の無水メタノールと $3 \mathrm{~g}$ の浱硫酸を加え て加熱還流する。反応が進むにしたがって反応混合物は次第に透 明な溶液となる。 2 時間反応を行なうと, 混合物は完全に透明な 溶液となるのでこのときに反応を停止する。反応終了後反応混合 物を冷却して $500 \mathrm{ml}$ の水中に，はげしくかきまぜながら投入す ると白色の沈殿 ( $\mathrm{A}$, 後述)が生成する。沈殿を口過, 乾燥してメ タノールから再結晶すると $\mathrm{mp} 235^{\circ} \mathrm{C}$ のイソシンコメロン酸-2メチルエステルの白色針状結晶 $8.7 \mathrm{~g}$ が得られる。収率 $95.6 \%$ 。 分析值 C $53.27 \%, \mathrm{H} 4.01 \%, \mathrm{~N} 7.56 \%$ $\mathrm{C}_{8} \mathrm{H}_{7} \mathrm{NO}_{4}$ としての

計算值 C $53.02 \%, \mathrm{H} 3.90 \%, \mathrm{~N} 7.74 \%$ 紫外吸収スペクトル*4: $\lambda_{\max }, 230 \mathrm{~m} \mu(\varepsilon 12700), 273 \mathrm{~m} \mu(\varepsilon$ 5100)

赤外吸収スペクトル： $\nu_{\mathrm{C}}=0,1715,1741 \mathrm{~cm}^{-1}, \nu_{\mathrm{C}-\mathrm{O}} 1251$, $1277 \mathrm{~cm}^{-1}$

上に述べた II a の沈殿(A)をロ過して除いた口液に炭酸ナトリ ウムを加えて中和すると，ジメチルエステル(IIa)の沈殿が生成す る。

モノメチルエステル(IIa) $0.9 \mathrm{~g}(0.005 \mathrm{~mol})$ にメタノール $30 \mathrm{ml}$ を加えて加熱溶解したのち $80 \%$ ヒドラジンヒドラート $5 \mathrm{ml}$ を 加えて 2 時間加熱還流する。反応終了後混合物を冷却すると白绝 の沈殿が生成する。この沈殿をエタノールと水との混合溶媒から 再結晶すると, $\mathrm{mp} 219.5^{\circ} \sim 220.5^{\circ} \mathrm{C}$ (文献值6) $219^{\circ} \sim 221^{\circ} \mathrm{C}$ )の イソシンコメロン酸-2-ヒドラジド（VI)の白色針状結晶 $0.83 \mathrm{~g}$ が 得られる。収率 $92.2 \%$ 。

\section{分析值 N $23.08 \%$}

$\mathrm{C}_{7} \mathrm{H}_{7} \mathrm{~N}_{3} \mathrm{O}_{3}$ としての計算值 $\mathrm{N} 23.21 \%$

紫外吸収スペクトル(水溶液)： $\lambda_{\max } 227 \mathrm{~m} \mu(\varepsilon 9800), 275 \mathrm{~m} \mu$ (ع 6900)

II a $1 \mathrm{~g}$, メタノール $20 \mathrm{ml}$ および濃硫酸 $2 \mathrm{~g}$ を混合して，4 時間加熱睘流したのち混合物に $100 \mathrm{ml}$ の水を加えて, 炭酸ナト リウムの飽和水溶液で微アルカリ性とすると白色の沈殿が生成す る。沈殿を口過, 乾燥してメタノールから再結晶すると mp 164 ${ }^{\circ} \mathrm{C}$ のジメチルエステル(IIa) $0.7 \mathrm{~g}$ が得られる。

分析值 N 7.12\%

$\mathrm{C}_{9} \mathrm{H}_{9} \mathrm{NO}_{4}$ とし:との計算值 $\mathrm{N} \mathrm{7.18 \%}$

2.4.2 インシンコメロン酸-2-エチルエステル(IIb): I 16.7

*4紫外吸収スペクトルは日立分光光度計 EPU-2 型を用い て測定し，本報で述べる化合物は，一部の化合物を除い ていずれも 95\%エタノール溶液として測定した。 $\mathrm{g}(0.1 \mathrm{~mol})$ K $150 \mathrm{ml}$ のエタノールと $2 \mathrm{~g}$ の濃流酸を加えて 8.5 時間加熱還流すると, 反応混合物は透明な溶液となるので, ここで反応を停止して混合物を冷却すると白色の沈殿が生成す る。沈殿を口過, 水洗したのち乾燥してエタノールから再結晶す ると $\mathrm{mp} 250^{\circ} \sim 251^{\circ} \mathrm{C}$ のインンコメロン酸-2-エチルエステル の白色柱状結晶 $11.5 \mathrm{~g}$ が得られる。収率 $59.0 \%$ 。

分析値 $\mathrm{C} 55.14 \%, \mathrm{H} 4.84 \%, \mathrm{~N} 7.00 \%$

$\mathrm{C}_{9} \mathrm{H}_{9} \mathrm{NO}_{4}$ としての

計算值 C $55.38 \% ， \mathrm{H} 4.65 \% ， \mathrm{~N} 7.18 \%$ 紫外吸収スペクトル： $\lambda_{\max } 230.5 \mathrm{~m} \mu(\varepsilon 13000), 274 \mathrm{~m} \mu(\varepsilon$ 6600)

赤外吸収スペクトル： $\nu_{\mathrm{C}}=0 \mathrm{O} 1726 \mathrm{~cm}^{-1}, \nu_{\mathrm{C}-\mathrm{O}} 1267,1291 \mathrm{~cm}^{-1}$

II b $0.5 \mathrm{~g}$ とヒドラジンヒドラートとをエタノール溶液中で反 応させると $\mathrm{mp} 220^{\circ} \sim 222^{\circ} \mathrm{C}$ の VI がほとんど定量的に得られ る。

\section{5 イソシンコメロン酸ジエステルの部分加水分解}

2.5.1 イソシンコメロン酸-5-メチルエステル(IVa)： ジメチ ルエステル(Ia) $19.5 \mathrm{~g}(0.1 \mathrm{~mol})$ に $600 \mathrm{ml}$ のメタノールを加え て加温しながら溶解させたのち, この溶液に $5.6 \mathrm{~g}(0.1 \mathrm{~mol})$ の水 酸化カリウムを $100 \mathrm{ml}$ のメタノールに溶かした溶液を加える。 混合溶液を加熱還流すると数分後に白色の沈殿 ( B , 後述)が生成 するが，そのまま 2 時間加熱還流したのち冷却して得られた沈殿 を口過, 乾燥したのち $300 \mathrm{ml}$ の水に溶解して, 濃塩酸 $15 \mathrm{ml}$ を 加光ると白色の沈殿が生成する。この沈殿を口過, 水洗, 乾燥し たのちメタノールから再結晶すると $\mathrm{mp} 186^{\circ} \mathrm{C}$ のイソシンコメ ロン酸-5-メチルエステルの白色針状結晶 $15.0 \mathrm{~g}$ が得られる。 収率 $82.9 \%$ 。

$\mathrm{C}_{8} \mathrm{H}_{7} \mathrm{NO}_{4}$ としての

分析值 $\mathrm{C} 53.28 \%, \mathrm{H} 4.13 \%, \mathrm{~N} 7.53 \%$

計算值 C $53.02 \%$, H $3.90 \%, \mathrm{~N} \mathrm{7.74 \%}$ 紫外吸収スペクトル： $\lambda_{\max } 229.5 \mathrm{~m} \mu(\varepsilon \quad 13000), 273 \mathrm{~m} \mu(\varepsilon$ 5000)

赤外吸収スペクトル： $\nu_{\mathrm{C}=0} 1705,1726 \mathrm{~cm}, \nu \mathrm{C}-\mathrm{O} 1292 \mathrm{~cm}^{-1}$

Ia を部分加水分解して得られた沈殿（B）を口過した口液から メタノールを留去して, 残留する白色の結晶に水 $200 \mathrm{ml}$ を加立, 溶解して不溶物 (mp $163^{\circ} \sim 164^{\circ} \mathrm{C}$, 未反応の 耼)を除いたのち, 浱塩酸 $5 \mathrm{ml}$ を加えると白色の沈殿が 生成する。この沈殿を口 過, 水洗, 乾燥後メタノールから再結晶すると $\mathrm{mp} 235^{\circ} \mathrm{C}$ の白 色針状結晶 $2.0 \mathrm{~g}$ が得られる。これは II 点降下を示さなかった。また元素分析結果から IIaであることが 明らかとなった。収率 $11.0 \%$ 。

\section{分析值 $\mathrm{N} 7.90 \%$}

$\mathrm{C}_{8} \mathrm{H}_{7} \mathrm{NO}_{4}$ としての計算值 $\mathrm{N} \mathrm{7.74 \%}$

$\mathrm{Na} 1 \mathrm{~g}$ を2.4.1 で述べた IIa のエステル化と同じ方法でエス テル化すると $\mathrm{mp} 164^{\circ} \mathrm{C}$ のジメチルエステル(Ia)0.9 g が得ら れる。

2.5.2 インシンコメロン酸-5-ヒドラジド(VII): モノメチル エステル $(\mathrm{IVa}) 5.0 \mathrm{~g}(0.028 \mathrm{~mol})$ にメタノール $50 \mathrm{ml}$ を加えて加 熱溶解したのち， $80 \%$ ヒドラジンヒドラート $25 \mathrm{ml}$ を加えると ただちに沈殿が生成する。混合物をとのまま 2 時間加熱還流した のち泠却して沈殿を口過, 乾燥, メタノールと水との混合溶媒か ら再結晶寸ると $\mathrm{mp} 286^{\circ} \sim 287^{\circ} \mathrm{C}$ (分解)のインシンコメロン酸一 
5-ヒドラジドの白色針状結晶 $3.5 \mathrm{~g}$ が得られる。収率 $70.0 \%$ 。 分析值 $\mathrm{N} 23.13 \%$

$\mathrm{C}_{7} \mathrm{H}_{7} \mathrm{~N}_{3} \mathrm{O}_{3}$ としての計算值 $\mathrm{N} 23.21 \%$

紫外吸収スベクトル(水溶液)： $\lambda_{\max } 222.5 \mathrm{~m} \mu(\varepsilon 8800), 273$ $\mathrm{m} \mu(\varepsilon$ 5700)

2.5.3 イソシンコメロン酸-5-エチルエステル(IVb): ジエチ ルエステル(Ib) $5 \mathrm{~g}(0.022 \mathrm{~mol}) k 10 \mathrm{ml}$ のエタノールを加えて 溶かし, この溶液に $1.2 \mathrm{~g}(0.022 \mathrm{~mol})$ の水酸化カリウムを 10 $\mathrm{m} l$ のエタノールに溶かした溶液を加えて 1 時間加熱還流したの ち冷却して, 生じた白色沈殿を口過, 乾燥後 $50 \mathrm{ml}$ の水に溶か して濃塩酸 $1.8 \mathrm{~m} l$ を加えると白色沈殿が生成する。この沈殿を 口過, 水洗, 乾燥後エタノールから再結晶すると $\mathrm{mp} 185^{\circ}$ ～ $186.5^{\circ} \mathrm{C}$ のインシンコメロン酸-5-エチルエステルの白色結晶 3.1 g が得られる。収率 70.5\%。

$\mathrm{C}_{9} \mathrm{H}_{9} \mathrm{NO}_{4}$ としての

分析値 C $55.42 \%, \mathrm{H} 4.81 \%, \mathrm{~N} 7.13 \%$

計算值 C $55.38 \%, \mathrm{H} 4.65 \%, \mathrm{~N} 7.18 \%$ 紫外吸収スベクトル： $\lambda_{\max } 229.5 \mathrm{~m} \mu(\varepsilon$ 14100), $273 \mathrm{~m} \mu(\varepsilon$ 6400)

赤外吸収スペクトル： $\nu \mathrm{c}=0 \quad 1718 \mathrm{~cm}^{-1}, \nu \mathrm{c}-\mathrm{o} 1246,1280 \mathrm{~cm}^{-1}$ IVb $0.5 \mathrm{~g}$ とヒドラジンヒドラートとの反応により $\mathrm{mp} 280^{\circ} \mathrm{C}$ (分解)の VI が定量的に得られる。

\subsection{6-メチルニコチン酸メチルエステル(IX)}

過マンガン酸カリウム $474 \mathrm{~g}(3 \mathrm{~mol})$ を水 $15 l$ に溶解して, $0^{\circ}$ 〜20C に冷却，かきまぜながらアルデヒドコリジン $121 \mathrm{~g}(1$ mol)を 2 時間で少量ずつ加える。反応混合物を $15^{\circ} \sim 20^{\circ} \mathrm{C}$ にた もちながら 30 時間反応を行なうと, 過マンガン酸カリウムの紫 色が消えて二酸化マンガンの沈殿が生成する。反応終了後沈殿を 口過して, 口液を蒸発乾固すると白色の残留物が得られる。乙 の残留物に $1.5 l$ のメタノールを加えたのち, 濃硫酸 $341 \mathrm{~g}$ を 加えて 10 時間加熱還流, 冷却したのち不溶物を口過して除き, 口液に炭酸ナトリウムの飽和溶液を加えて微アルカリ性としてク ロロホルムで抽出する。抽出液を無水炭酸カリウムで乾燥して溶 媒を留去, 減圧蒸留すると $\mathrm{bp}_{11} 100^{\circ} \sim 102^{\circ} \mathrm{C}$ の無色透明な液体 として 6-メチルニコチン酸メチルエステルが得られる。この液 体はただちに結晶する。 $\mathrm{mp} 32^{\circ} \mathrm{C}$, 収量 $61.5 \mathrm{~g}$, 収率 $40.7 \%$ 。

\subsection{6 -ホルミルニコチン酸メチルエステル $(\mathbf{X})$}

新しく精製した二酸化セレン $14.4 \mathrm{~g}(0.13 \mathrm{~mol})$ に $60 \mathrm{ml}$ のシ オキサンと $2.5 \mathrm{~m} l$ の水との混合液を加えて $60^{\circ} \sim 65^{\circ} \mathrm{C}$ に加熱 して，二酸化セレンを溶解させる。これに $20 \mathrm{~g}(0.13 \mathrm{~mol}) の \mathbb{X}$ を $40 \mathrm{ml}$ のシオキサンに溶かした 溶液をかきまぜながら徐々に 加えると，反応混合物は次第に赤褐色から暗褐色に着色して，金 属セレンが沈降する。 $60^{\circ} \sim 65^{\circ} \mathrm{C}$ で 1 時間反応を行なったのち, 熱時金属セレンをロ別する。口液から減压下でシオキサンを留去 して残留物を乾燥エーテルで抽出する。抽仙液からエーテルを留 去すると淡黄色の固体が得られる。これをエーテルから数回再結 晶をくり返すと $\mathrm{mp} 122^{\circ} \sim 122.5^{\circ} \mathrm{C}$ の 6-ホルミルニコチン酸メ チルエステルの白色結晶 $8 \mathrm{~g}$ が得られる。収率 $36.6 \%$ 。

分析值 C $58.31 \%, \mathrm{H} 4.32 \%, \mathrm{~N} 8.48 \%$

$\mathrm{C}_{9} \mathrm{H}_{7} \mathrm{NO}_{3}$ としての
計算値 C $58.16 \%, \mathrm{H} 4.27 \%, \mathrm{~N} 8.49 \%$ 紫外吸収スペクトル： $\lambda_{\max } 226 \mathrm{~m} \mu(\varepsilon \quad 11500), 266 \mathrm{~m} \mu(\varepsilon$ $4600), 274 \mathrm{~m} \mu(\varepsilon 4000$, 肩)

赤外吸収スペクトル： $\nu_{\mathrm{C}}=0.1721 \mathrm{~cm}^{-1}, \nu_{\mathrm{C}-\mathrm{O}} 1288 \mathrm{~cm}^{-1}$

2.86 -ホルミルニコチン酸メチルエステル-2,4-ジニトロフェ ニルヒドラゾン $(\mathbf{X I})$

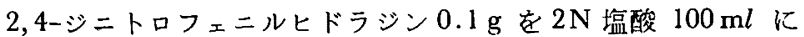
溶かした溶液に，ピリジンアルデヒド（X) $0.1 \mathrm{~g}$ を加えて溶解し たのち，はげしくかきまぜると橙色の沈殿が生成する。この沈殿 を口過, 乾燥後エタノールから 3 回再結晶を行なうと $\mathrm{mp} 223^{\circ}$ 〜

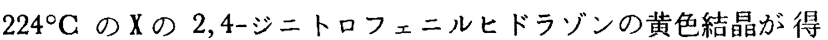
られる。

分析值 C $48.94 \%, \mathrm{H} 3.28 \%, \mathrm{~N} 20.01 \%$

$\mathrm{C}_{14} \mathrm{H}_{11} \mathrm{~N}_{5} \mathrm{O}_{6}$ としての

計算值 C $48.70 \% ， \mathrm{H} 3.21 \% ， \mathrm{~N} 20.28 \%$

\section{9 ピリジンアルデヒド $(\mathbf{X})$ の過酸化水素による酸化}

$30 \%$ 過酸化水素水 $3 \mathrm{~m} l$ を $60^{\circ} \mathrm{C}$ に加温してはげしくかきま ぜながらピリジンアルデヒド (X) $1.0 \mathrm{~g}$ を少量ずつ 30 分間で加 える。Xが溶解したのち, 過酸化水素水 $1.5 \mathrm{ml}$ を追加して, 70 ${ }^{\circ} \mathrm{C}$ で 1 時間反応を行なうと白色の沈殿が生成する。室温まで冷 却して沈殿を口過, メタノールから再結晶を行なうと $\mathrm{mp} 186^{\circ} \mathrm{C}$ の白色針状結晶 $0.6 \mathrm{~g}$ が得られる。これは 2.5.1で述べたイソ シンコメロン酸-5-メチルエステル(Na)との混融試験の結果, 融 点降下を示さず，赤外吸収スペクトルおよび 紫外吸収スペクトル も $\mathrm{Na}$ と一致した。したがってここに得られた白色結晶は $\mathrm{Na} と$ 同一物であることを認めた。

\section{分析值 $N 7.90 \%$}

$\mathrm{C}_{8} \mathrm{H}_{7} \mathrm{NO}_{4}$ としての計算值 $\mathrm{N} 7.74 \%$

2.8 における二酸化セレン酸化を $70^{\circ} \sim 95^{\circ} \mathrm{C}$ で行なうか，あ るいは, 二酸化セレンを過剩に用いて反応を行なうと，ピリジン アルデヒド $(X)$ の生成量が減少し, 大部分がモノェステル (IVa) となる。

$2.105,5$-ジメトキシカルボニル-a-ピリドイン $(\mathbf{X I I})$

X $0.3 \mathrm{~g}(0.0018 \mathrm{~mol})$ をタノール $30 \mathrm{~m} l$ に溶かし, $10 \%$ シ アン化カリウム水溶液 $3 \mathrm{~m} l$ を滴下すると, ただちに赤色に着色 する。これを水浴中で加温すると橙色の沈殿が生成する。アセ トンとベンゼンの混合溶液から再結晶すると $\mathrm{mp} 227^{\circ} \sim 228^{\circ} \mathrm{C}$

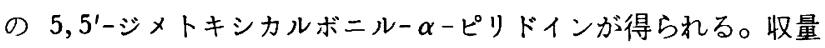
$0.12 \mathrm{~g}$, 収率 $40.0 \%$

分析值 C $57.99 \%, \mathrm{H} 4.01 \%, \mathrm{~N} 8.37 \%$

$\mathrm{C}_{18} \mathrm{H}_{14} \mathrm{~N}_{2} \mathrm{O}_{6}$ としての

計算值 C $58.16 \% ， \mathrm{H} 4.27 \%$ ．N 8.49\% 紫外吸収スペクトル： $\lambda_{\max } 229.5 \mathrm{~m} \mu(\varepsilon 30600), 272 \mathrm{~m} \mu(\varepsilon$ 13400)

赤外吸収スペクトル： $\nu_{\mathrm{C}}=0 \mathrm{O} 1721 \mathrm{~cm}^{-1}, \nu_{\mathrm{C}-\mathrm{O}} 1292 \mathrm{~cm}^{-1}$

終りに試料の御提供ならびに種々の御支援を賜わった三菱化成 工業株式会社に感謝致します。また赤外吸収スペクトルを測定し ていただいた東北大学理学部化学教室 IRDC の方々に感謝致し ます。 